ISSN 0258-7122 (Print), 2408-8293 (Online)

Bangladesh J. Agril. Res. 42(1): 1-11, March 2017

\title{
EVALUATION OF PUMPKIN (Cucurbita moschata Duch. Ex Poir.) FOR YIELD AND OTHER CHARACTERS*
}

\author{
B. AHMED ${ }^{1}$, M. A. T. MASUD ${ }^{2}$, M. ZAKARIA ${ }^{3}$ \\ M. M. HOSSAIN ${ }^{3}$ AND M. A. K. MIAN ${ }^{4}$
}

\begin{abstract}
Nineteen inbreds of pumpkin (Cucurbita moschata Duch. Ex Poir.) were evaluated at the experimental farm of Olericulture Division, Horticulture Research Centre, Bangladesh Agricultural Research Institute, Gazipur during the rabi season of 2011-12 to select the promising inbreds for higher fruit yield along with other important characters. Thirteen quantitative and three qualitative characters along with fruit fly infestation and virus incidence were studied. The inbreds differed significantly in most of the quantitative characters. All the qualitative characters (fruit shape, fruit skin colour and flesh colour) showed distinct variation among the inbreds. All the inbreds except PK05, PK16, PK17 and PK18 were attacked with Water Melon Virus 2 (WMV2). Fruits of all the lines were more or less infested by fruit fly. The study revealed that the inbreds differing significantly in most of the parameters offer a good scope of selection of better inbreds for desired traits. The flesh thickness, average fruit weight, fruits per plant ranged from 2.61 to $5.39 \mathrm{~cm}, 1.41$ to $5.78 \mathrm{~kg}$ and 2.96 to 7.58 respectively. On the basis of yield and other yield attributes nine inbreds viz., PK01, PK02, PK03, PK06, PK07, PK08, PK09, PK10 and PK16 were found promising. These inbreds will be helpful in breeding program to evolve high yielding varieties of pumpkin with better quality.
\end{abstract}

Keywords: Pumpkin, Cucurbita moschata, inbreds, selection, fruit yield.

\section{Introduction}

Pumpkin (Cucurbita moschata Duch. Ex Poir.) is one of the major cucurbitaceous fruit vegetables grown all over Bangladesh. The crop is variously known as 'Misti kumra' or 'Misti lau' or 'Misti kadu' in different parts of Bangladesh and is consumed by most of the people of the country. Its fruits are extensively used as vegetables both in immature and mature stage. The yellow and orange flesh fruits are very rich in carotene which is the precursor of Vitamin A with Vitamins B and $\mathrm{C}$, and it is particularly important for the supply of antioxidants and especially carotenoids in foods (Gupta and Rai, 1990). It is very popular among the farmers

\footnotetext{
* a part of $\mathrm{PhD}$ dissertation of the first author.

${ }^{1}$ Senior Scientific Officer, ${ }^{2}$ Principal Scientific Officer and PD, Horticulture Research Center, Bangladesh Agricultural Research Institute (BARI), Gazipur, ${ }^{3}$ Professor, Department of Horticulture, ${ }^{4}$ Professor, Department of Genetics and Plant Breeding, Bangabandhu Sheikh Mujibur Rahman Agricultural University (BSMRAU), Salna, Gazipur, Bangladesh.
} 
owing to its good taste, high nutritive value, good storability and long time of availability and better transport potentialities (Hazra et al., 2007; Rashid, 1999). For these reasons its demand is increasing day by day in the country. Pumpkin grows both in rabi and kharif seasons in Bangladesh. About 14\% (8\% in rabi and $6 \%$ in kharif seasons) of the total vegetable production comes from pumpkin (BBS, 2013). It ranks $3^{\text {rd }}$ in respect of both area and production next to brinjal and radish. In Bangladesh, it occupies an area 27,500 ha with an annual production of 2,18,000 tons accounting to an average yield of $7.93 \mathrm{t} / \mathrm{ha}$ (BBS, 2013) that is miserably low compared to that of other countries like India, China, Iran, Egypt, Australia, etc. It is assumed that more than $20 \mathrm{t} /$ ha yield of pumpkin is satisfactory (Rashid, 1999). There are many factors responsible for this low yield of pumpkin. Among them, lack of high yielding varieties of pumpkin appears to be the most vital factor. Though a fairly common crop, to-date there are a few recommended varieties in Bangladesh. It is required sufficient number of high yielding varieties (HYVs) to meet the ever increasing demand of the farmers and the nutritional requirement of people. This can be achieved through massive breeding programs. The success of any crop improvement depends on the amount of genetic variability present in the population. Pumpkin genotypes grown in different parts of Bangladesh have enormous variability among them. There are number of local cultivars/land races with wide range of variability in size, shape and colour of fruits available in Bangladesh (Rashid, 1993; Kamaluddin, 1996). Many scientists reported significant variations present in pumpkin genotypes (Ahmed et al., 2011; Akter et al., 2013; Aruah et al., 2012). In order to develop HYVs of Pumpkin the Olericulture Division, HRC, BARI collected a good number of pumpkin germplasm and developed 19 inbreds. Genotypes available in the population do not have uniformity, and thus 19 inbreds have also variability among them. Since there exists a considerable variability in this crop, it is possible to develop HYVs through breeding approaches like selection or hybridization. The present investigation was therefore, conducted to select the promising pumpkin inbred (s) in respect of yield and other important characters with a view to developing high yielding variety (ies) through hybridization.

\section{Materials and Method}

The experiment was carried out at the experimental farm of Olericulture Division, Horticulture Research Centre (HRC), Bangladesh Agricultural Research Institute (BARI) Gazipur, Bangladesh during October 2011 to May 2012. Nineteen pumpkin inbreds (PK01, PK02, PK03, PK04, PK05, PK06, PK07, PK08, PK09, PK10, PK11, PK12, PK13, PK14, PK15, PK16, PK17, PK18 and PK19) were used in this study. The inbreds were collected from the Olericulture Division, HRC, BARI. The experiment was laid out in a Randomized Complete Block Design with three replications. The land was first opened by mould board plough. Three times harrowing were applied to pulverize the soil followed by laddering to have a good tilth. All types of weeds and debris of the previous crop (spinach) were removed. The unit plot size was $2 \mathrm{~m} \times 10 \mathrm{~m}$ and the plots were raised by $10 \mathrm{~cm}$ from the 
ground level. Five pits of $50 \mathrm{~cm} \times 50 \mathrm{~cm} \times 30 \mathrm{~cm}$ size were prepared in each plot at a spacing of $2 \mathrm{~m}$ plant to plant by keeping $60 \mathrm{~cm}$ width drain between the plots. About $25 \mathrm{~cm}$ deep drain was dug around the plot. Seeds were sown in $9 \mathrm{~cm}$ diameter polyethylene bags. The growth medium was prepared by mixing compost and soil in 50: 50 proportion. Intensive care was taken for healthy seedling production. Twenty five days old seedlings were transplanted in well prepared experimental plot. The seedlings were watered immediately after transplanting. Fertilizers were applied @ 5000-78-35-75-18-4.3-2 kg/ha of cowdung-N-P-K-S$\mathrm{Zn}-\mathrm{B}$. The sources of N, P, K, S, Zn and B were urea, TSP, MoP, gypsum, zinc sulphate and boric acid (medicated) respectively (Anon, 2012). The entire amount of cowdung, $\mathrm{P}, \mathrm{S}, \mathrm{Zn}, \mathrm{B}$ and $1 / 3^{\text {rd }} \mathrm{K}$ were applied during pit preparation as basal dose before 10 days of transplanting. The rest amount of $\mathrm{K}$ was applied in two equal installments at 20 and 35 days after transplanting (DAT). $\mathrm{N}$ was applied in four equal installments at 7,20,35 and 50 DAT.

Necessary intercultural operations such as irrigation, weeding, mulching pits etc were done during the crop period for proper growth and development of the plants. Control measure was taken against red pumpkin betel by spraying Ripcord @ 1ml/liter of water over seeding once per week for 2 times. At fruiting stage, sex pheromone traps and meshed sweet gourd traps were set up in a density of $5 \mathrm{~m}^{2} /$ trap to control the infestation of fruit fly. The fruits were harvested when the fruit stalk dried and shrivelled. Data were collected from five mature fruits from all the plants of inbreds. Data on different characters were recorded based on the descriptors for pumpkin developed by the International Board of Plant Genetic Resources (IBPGR). The recorded data for different characters were analyzed using software Statistic 10 and means were separated by DMRT at $1 \%$ level of probability.

\section{Results and Discussion}

Results pertaining to different characters under study are furnished below:

\section{Days to first male flower}

Significant variation was observed among the inbreds for days to first male flower of pumpkin (Table 1). Days to first male flower ranged from 64.50 to 80.63 days. The maximum days to first male flower was recorded in PK01 (80.63) closely followed by PK11 (78.08), PK19 (77.00), PK16 (77.00) and PK17 (77.00) and the lowest days to first male flower were found in PK08 (64.50). Rasul and Raihan (2014) also reported to have significant variation for days to first male flower in different pumpkin genotypes which ranged from 72 to 86 .

\section{Days to first female flower}

Days to first female flower ranged from 77.25 to 88.50 days (Table 1). The maximum days to first female flower was observed in PK01 (88.50) which was statistically similar to PK04 (87.42), PK05 (87.28), PK19 (86.50), PK03 (85.75), 
PK16 (85.25), PK01 (84.25) and PK14 (83.75). The minimum days to first female flower was observed in PK12 (77.25) which was identical with PK13 (79.25), PK09 (79.50), PK10 (79.50), PK08 (80.00), PK07 (81.75) and PK06 (82.00). Akter et al. (2011) reported significant variation for days to first female flower in nine pumpkin genotypes which ranged from 86 to 92 .

\section{Node number of first male flower}

Significant variation was noticed in node number of first male flower and it ranged from 5.08 to 8.63 (Table 1). The highest node number of first male flower was recorded in PK10 (8.63) which was statistically similar with all other inbreds except PK02, PK04, PK08, PK13 and PK17. The lowest node number of first male flower was recorded in PK04 (5.08). Mohanty and Mishra (2002) evaluated eight diverse genotypes of pumpkin and found that node number of first male flower showed significant difference, which ranged from 5 to 9 and Akter et al. (2011) reported node number of first male flower varied from 6 to 11.

Table 1. Performance of 19 pumpkin inbreds for different reproductive characters

\begin{tabular}{l|c|c|c|c}
\hline Inbreds & $\begin{array}{c}\text { Days to 1 } \\
\text { male flower }\end{array}$ & $\begin{array}{c}\text { Days to } 1^{\text {st }} \\
\text { female flower }\end{array}$ & $\begin{array}{c}\text { Node number of } \\
1^{\text {st }} \\
\text { male flower }\end{array}$ & $\begin{array}{c}\text { Node number of } \\
1^{\text {st }} \text { female flower }\end{array}$ \\
\hline PK 01 & $80.63 \mathrm{a}$ & $88.50 \mathrm{a}$ & $7.00 \mathrm{ab}$ & $20.25 \mathrm{a}-\mathrm{c}$ \\
PK 02 & $73.25 \mathrm{c}-\mathrm{g}$ & $83.00 \mathrm{~b}-\mathrm{e}$ & $5.50 \mathrm{~b}$ & $17.25 \mathrm{c}$ \\
PK 03 & $76.38 \mathrm{~b}-\mathrm{d}$ & $85.75 \mathrm{a}-\mathrm{c}$ & $6.13 \mathrm{ab}$ & $19.13 \mathrm{a}-\mathrm{c}$ \\
PK 04 & $70.13 \mathrm{fg}$ & $87.42 \mathrm{ab}$ & $5.08 \mathrm{~b}$ & $19.29 \mathrm{a}-\mathrm{c}$ \\
PK 05 & $76.50 \mathrm{~b}-\mathrm{d}$ & $87.28 \mathrm{ab}$ & $6.40 \mathrm{ab}$ & $22.13 \mathrm{a}$ \\
PK 06 & $71.13 \mathrm{e}-\mathrm{g}$ & $82.00 \mathrm{c}-\mathrm{f}$ & $6.38 \mathrm{ab}$ & $20.38 \mathrm{a}-\mathrm{c}$ \\
PK 07 & $70.13 \mathrm{fg}$ & $81.75 \mathrm{c}-\mathrm{f}$ & $7.88 \mathrm{ab}$ & $21.50 \mathrm{ab}$ \\
PK 08 & $64.50 \mathrm{~h}$ & $80.00 \mathrm{~d}-\mathrm{f}$ & $5.13 \mathrm{~b}$ & $19.75 \mathrm{a}-\mathrm{c}$ \\
PK 09 & $70.00 \mathrm{fg}$ & $79.50 \mathrm{~d}-\mathrm{f}$ & $7.38 \mathrm{ab}$ & $20.13 \mathrm{a}-\mathrm{c}$ \\
PK 10 & $69.50 \mathrm{~g}$ & $79.50 \mathrm{~d}-\mathrm{f}$ & $8.63 \mathrm{a}$ & $18.88 \mathrm{a}-\mathrm{c}$ \\
PK 11 & $78.08 \mathrm{ab}$ & $83.69 \mathrm{~b}-\mathrm{e}$ & $7.21 \mathrm{ab}$ & $18.73 \mathrm{a}-\mathrm{c}$ \\
PK 12 & $69.25 \mathrm{~g}$ & $77.25 \mathrm{f}$ & $6.63 \mathrm{ab}$ & $18.00 \mathrm{bc}$ \\
PK 13 & $72.55 \mathrm{~d}-\mathrm{g}$ & $79.25 \mathrm{ef}$ & $5.63 \mathrm{~b}$ & $19.93 \mathrm{a}-\mathrm{c}$ \\
PK 14 & $74.88 \mathrm{~b}-\mathrm{e}$ & $83.75 \mathrm{a}-\mathrm{e}$ & $7.13 \mathrm{ab}$ & $18.88 \mathrm{a}-\mathrm{c}$ \\
PK 15 & $75.13 \mathrm{~b}-\mathrm{e}$ & $83.63 \mathrm{~b}-\mathrm{e}$ & $7.00 \mathrm{ab}$ & $19.13 \mathrm{a}-\mathrm{c}$ \\
PK 16 & $77.00 \mathrm{a}-\mathrm{c}$ & $85.25 \mathrm{a}-\mathrm{c}$ & $7.75 \mathrm{ab}$ & $18.13 \mathrm{bc}$ \\
PK 17 & $77.00 \mathrm{a}-\mathrm{c}$ & $84.25 \mathrm{a}-\mathrm{d}$ & $5.63 \mathrm{~b}$ & $17.75 \mathrm{c}$ \\
PK 18 & $75.88 \mathrm{~b}-\mathrm{d}$ & $83.48 \mathrm{~b}-\mathrm{e}$ & $7.50 \mathrm{ab}$ & $18.75 \mathrm{a}-\mathrm{c}$ \\
PK 19 & $77.00 \mathrm{a}-\mathrm{c}$ & $86.50 \mathrm{a}-\mathrm{c}$ & $5.88 \mathrm{ab}$ & $20.50 \mathrm{a}-\mathrm{c}$ \\
\hline Range & $64.50-80.63$ & $77.25-88.50$ & $5.08-8.63$ & $17.25-22.13$ \\
CV (\%) & 4.01 & 3.89 & 11.54 & 8.93 \\
\hline
\end{tabular}

Means with uncommon letter(s) differ significantly by DMRT at $1 \%$ level 


\section{Node number of first female flower}

Statistically significant variation was observed in pumpkin inbreds in respect of node number of first female flower which ranged from 17.25 to 22.13 (Table 1). The maximum node number of first female flower was found in PK05 (22.13) which was statistically similar with the other inbreds except PK02, PK12, PK 16 and PK17 while the lowest node number of first female flower was recorded in PK02 (17.25). Mohanty and Mishra (2002) evaluated eight diverse genotypes of pumpkin and reported that node number of first female flower showed significant variation ranging from 15 to 26 .

\section{Fruit length (cm)}

Fruit length differed significantly and ranged from 9.73 to $38.65 \mathrm{~cm}$ (Table 2). The highest fruit length was found in PK02 $(38.65 \mathrm{~cm})$ while the lowest fruit length was found in PK17 $(9.73 \mathrm{~cm})$ which was statistically similar with PK08 $(13.54 \mathrm{~cm})$ and PK09 $(12.13 \mathrm{~cm})$. Rouf et al. (2011) observed significant variation for fruit length in pumpkin which ranged from 10.50 to $24.60 \mathrm{~cm}$.

\section{Fruit diameter $(\mathbf{c m})$}

Marked variation was observed among the inbreds with regard to fruit diameter (Table 2). It ranged from 14.04 to $25.44 \mathrm{~cm}$. The maximum fruit diameter was observed in PK03 $(25.44 \mathrm{~cm})$ which was closely followed by PK13 $(24.37 \mathrm{~cm})$, PK11 $(24.12 \mathrm{~cm})$ and PK07 $(24.01 \mathrm{~cm})$ and the minimum fruit diameter was observed in PK02 $(14.04 \mathrm{~cm})$ which was identical with PK17 $(15.99 \mathrm{~cm})$ and PK01 $(16.25 \mathrm{~cm})$. This variation might be due to the inherent genotypic variability of different inbreds used in this study. Rouf et al. (2011) observed significant variation for fruit diameter in pumpkin ranging from 8.50 to 28.30 $\mathrm{cm}$.

\section{Cavity length (cm)}

Significant variation was observed among the inbreds of pumpkin regarding cavity length (Table 2). The highest cavity length was recorded in PK02 (30.33 $\mathrm{cm})$ and the lowest cavity length in PK17 $(4.75 \mathrm{~cm})$ which was statistically similar to PK08 $(7.25 \mathrm{~cm})$, PK19 $(7.42 \mathrm{~cm})$, PK04 $(7.53 \mathrm{~cm})$, PK15 $(7.63 \mathrm{~cm})$, PK11 $(8.08 \mathrm{~cm})$, PK12 $(8.35 \mathrm{~cm})$, PK01 $(8.69 \mathrm{~cm})$ and PK03 $(8.71 \mathrm{~cm})$.

\section{Cavity width (cm)}

Significant variation among the inbreds was observed for this trait (Table 2). The maximum cavity width was obtained from PK11 $(15.27 \mathrm{~cm})$ and PK12 (15.28 $\mathrm{cm})$ closely followed by the other inbreds except PK01, PK05, PK09, PK14 and PK16. The lowest cavity width was obtained from PK01 $(9.84 \mathrm{~cm})$. 
Table 2. Performance of $\mathbf{1 9}$ pumpkin inbreds for different fruit characters

\begin{tabular}{l|c|c|c|c|c}
\hline \multicolumn{1}{c}{ Inbreds } & $\begin{array}{c}\text { Fruit length } \\
(\mathrm{cm})\end{array}$ & $\begin{array}{c}\text { Fruit diameter } \\
(\mathrm{cm})\end{array}$ & $\begin{array}{c}\text { Cavity } \\
\text { length }(\mathrm{cm})\end{array}$ & $\begin{array}{c}\text { Cavity } \\
\text { width }(\mathrm{cm})\end{array}$ & $\begin{array}{c}\text { TSS } \\
(\%)\end{array}$ \\
\hline PK01 & $16.19 \mathrm{f}-\mathrm{h}$ & $16.25 \mathrm{~g}-\mathrm{i}$ & $8.69 \mathrm{~d}-\mathrm{i}$ & $9.84 \mathrm{~cd}$ & $9.29 \mathrm{~b}-\mathrm{d}$ \\
PK02 & $38.65 \mathrm{a}$ & $14.04 \mathrm{i}$ & $30.33 \mathrm{a}$ & $14.00 \mathrm{ab}$ & $8.13 \mathrm{~d}-\mathrm{f}$ \\
PK03 & $20.24 \mathrm{~b}-\mathrm{e}$ & $25.44 \mathrm{a}$ & $8.71 \mathrm{~d}-\mathrm{i}$ & $14.00 \mathrm{ab}$ & $8.42 \mathrm{~d}-\mathrm{f}$ \\
PK04 & $15.51 \mathrm{f}-\mathrm{h}$ & $20.35 \mathrm{de}$ & $7.53 \mathrm{f}-\mathrm{i}$ & $12.26 \mathrm{a}-\mathrm{c}$ & $8.21 \mathrm{~d}-\mathrm{f}$ \\
PK05 & $15.89 \mathrm{f}-\mathrm{h}$ & $18.94 \mathrm{~d}-\mathrm{f}$ & $9.73 \mathrm{~d}-\mathrm{h}$ & $11.47 \mathrm{bc}$ & $7.88 \mathrm{ef}$ \\
PK06 & $21.21 \mathrm{bc}$ & $20.14 \mathrm{de}$ & $12.71 \mathrm{~b}-\mathrm{d}$ & $12.35 \mathrm{a}-\mathrm{c}$ & $7.38 \mathrm{f}$ \\
PK07 & $20.42 \mathrm{~b}-\mathrm{d}$ & $24.01 \mathrm{ab}$ & $12.06 \mathrm{~b}-\mathrm{e}$ & $13.66 \mathrm{ab}$ & $8.31 \mathrm{~d}-\mathrm{f}$ \\
PK08 & $13.54 \mathrm{~g}-\mathrm{i}$ & $20.08 \mathrm{de}$ & $7.25 \mathrm{~g}-\mathrm{i}$ & $12.50 \mathrm{a}-\mathrm{c}$ & $9.96 \mathrm{a}-\mathrm{c}$ \\
PK09 & $12.13 \mathrm{~h}-\mathrm{i}$ & $17.60 \mathrm{f}-\mathrm{h}$ & $6.14 \mathrm{hi}$ & $11.52 \mathrm{bc}$ & $8.48 \mathrm{~d}-\mathrm{f}$ \\
PK10 & $19.44 \mathrm{c}-\mathrm{f}$ & $20.37 \mathrm{de}$ & $11.49 \mathrm{c}-\mathrm{g}$ & $11.86 \mathrm{a}-\mathrm{c}$ & $9.13 \mathrm{c}-\mathrm{e}$ \\
PK11 & $14.89 \mathrm{gh}$ & $24.12 \mathrm{ab}$ & $8.08 \mathrm{e}-\mathrm{i}$ & $15.27 \mathrm{a}$ & $8.19 \mathrm{~d}-\mathrm{f}$ \\
PK12 & $15.81 \mathrm{f}-\mathrm{h}$ & $23.00 \mathrm{bc}$ & $8.35 \mathrm{~d}-\mathrm{i}$ & $15.28 \mathrm{a}$ & $10.60 \mathrm{ab}$ \\
PK13 & $16.93 \mathrm{~d}-\mathrm{g}$ & $24.37 \mathrm{ab}$ & $9.49 \mathrm{~d}-\mathrm{h}$ & $14.07 \mathrm{ab}$ & $9.17 \mathrm{c}-\mathrm{e}$ \\
PK14 & $20.38 \mathrm{~b}-\mathrm{d}$ & $19.50 \mathrm{~d}-\mathrm{f}$ & $11.75 \mathrm{c}-\mathrm{f}$ & $11.34 \mathrm{bc}$ & $10.75 \mathrm{a}$ \\
PK15 & $14.26 \mathrm{gh}$ & $18.42 \mathrm{e}-\mathrm{g}$ & $7.63 \mathrm{f}-\mathrm{i}$ & $12.65 \mathrm{a}-\mathrm{c}$ & $8.50 \mathrm{~d}-\mathrm{f}$ \\
PK16 & $24.28 \mathrm{~b}$ & $18.34 \mathrm{e}-\mathrm{h}$ & $16.19 \mathrm{~b}$ & $10.61 \mathrm{c}$ & $8.06 \mathrm{~d}-\mathrm{f}$ \\
PK17 & $9.73 \mathrm{i}$ & $15.99 \mathrm{hi}$ & $4.75 \mathrm{i}$ & $11.76 \mathrm{a}-\mathrm{c}$ & $8.65 \mathrm{c}-\mathrm{f}$ \\
PK18 & $24.19 \mathrm{~b}$ & $18.00 \mathrm{e}-\mathrm{h}$ & $14.54 \mathrm{bc}$ & $11.76 \mathrm{a}-\mathrm{c}$ & $8.32 \mathrm{~d}-\mathrm{f}$ \\
PK19 & $15.00 \mathrm{gh}$ & $21.33 \mathrm{~cd}$ & $7.42 \mathrm{f}-\mathrm{i}$ & $14.09 \mathrm{ab}$ & $10.00 \mathrm{a}-\mathrm{c}$ \\
\hline Range & $9.73-38.65$ & $14.04-25.44$ & $4.75-30.33$ & $9.84-15.28$ & $7.38-10.75$ \\
\hline CV $(\%)$ & 10.78 & 5.75 & 16.53 & 11.02 & 7.56 \\
\hline
\end{tabular}

Means with uncommon letter(s) differ significantly by DMRT at $1 \%$ level.

\section{TSS (\%)}

Significant differences were observed in TSS (\%) of pumpkin inbreds (Table 2). The TSS ranged from 7.38 to $10.75 \%$. The maximum TSS were found in PK14 (10.75\%) which was statistically similar to PK12 (10.60\%), PK19 (10.00\%) and PK08 (9.96\%). The lowest TSS was found in PK06 (7.38\%) which was identical with PK05 (7.88\%), PK16 (8.06\%), PK02 (8.13\%), PK11 (8.19\%), PK04 (8.21\%), PK07 (8.31\%), PK18 (8.32\%), PK03 (8.42\%), PK17 (8.65\%), PK09 $(8.48 \%)$ and PK15 (8.50\%). Islam et al. (2010) reported that TSS ranged from 6 
to $12 \%$ in pumpkin genotypes. Rouf et al. (2011) also found TSS in pumpkin varied from 6.10 to $9.10 \%$ which supports the present findings.

\section{Flesh thickness (cm)}

The flesh thickness of pumpkin differed significantly among the inbreds (Table $3)$. The highest flesh thickness was recorded in PK03 $(5.39 \mathrm{~cm})$ and the lowest flesh thickness was in PK09 $(2.61 \mathrm{~cm})$ which was statistically similar to PK18 $(2.95 \mathrm{~cm})$, PK08 $(2.96 \mathrm{~cm})$, PK17 $(3.06 \mathrm{~cm})$, PK16 $(3.11 \mathrm{~cm})$, PK01 $(3.13 \mathrm{~cm})$, PK15 $(3.19 \mathrm{~cm})$ and PK19 $(3.21 \mathrm{~cm})$. In the present study, flesh thickness ranged from 2.61 to $5.39 \mathrm{~cm}$, which is in agreement with the findings of Pandey et al. (2003).

\section{Average fruit weight $(\mathrm{kg})$}

Significant difference was observed in pumpkin inbreds in respect of average fruit weight ranged from 1.41 to $5.78 \mathrm{~kg}$ (Table 3). The maximum average fruit weight was recorded in PK03 (5.78 kg) closely followed by PK07 (4.86 kg) and the minimum average fruit weight in PK17 $(1.41 \mathrm{~kg})$ which was statistically similar to PK09 $(1.88 \mathrm{~kg})$, PK01 $(2.27 \mathrm{~kg})$ and PK15 $(2.33 \mathrm{~kg})$. Fruit weight differed from one another might be due to inherent character of the inbreds. Ahmed et al. (2011) reported significant variation present in average fruit weight and it ranged from 1.51 to $4.20 \mathrm{~kg}$. Pandey et al. (2003) obtained that the average fruit weight of pumpkin in the range of 1.33 to $9.10 \mathrm{~kg}$.

\section{Number of fruits per plant}

The inbreds varied significantly for this parameter (Table 3). Number of fruits per plant ranged from 2.96 to 7.58 . The highest number of fruits per plant was observed in PK09 (7.58) while the lowest number of fruits per plant was found in PK14 (2.96) closely followed by the other inbreds except PK01 (5.38), PK02 (5.13), PK09 (7.58) and PK16 (5.13). Ahmed et al. (2011) reported significant differences in fruit per plant in different pumpkin genotypes and the highest number of fruits per plant (15.74) was observed in one genotype. Akter et al. (2013) found fruits per plant ranging from 1.52 to 4.60.

\section{Fruit yield per plant (kg)}

The pumpkin inbreds exhibited a significant variation with regard to fruit yield per plant (Table 3). The fruit yield per plant ranged from 4.84 to $22.45 \mathrm{~kg}$. The maximum yield per plant was recorded in PK07 $(22.45 \mathrm{~kg})$ closely followed by PK03 (19.75 kg), PK02 (19.17 kg), PK16 (18.77 kg), PK13 (18.53 kg), PK06 $(17.35 \mathrm{~kg})$ and PK04 (15.79 kg) and the lowest yield per plant was obtained from PK17 (4.84 kg) which was identical with PK15 (7.62 kg), PK14 (10.23 kg) and PK08 (10.65 kg). Ahmed et al. (2011) obtained significant variation in yield per plant in different pumpkin genotypes in the range of 5.94 to $36.12 \mathrm{~kg}$. 
Table 3. Performance of 19 pumpkin inbreds for fruit yield and other characters

\begin{tabular}{l|c|c|c|c}
\hline Inbreds & $\begin{array}{c}\text { Flesh thickness } \\
(\mathrm{cm})\end{array}$ & $\begin{array}{c}\text { Average fruit } \\
\text { weight }(\mathrm{kg})\end{array}$ & $\begin{array}{c}\text { Number of fruits } \\
\text { per plant }\end{array}$ & $\begin{array}{c}\text { Fruit yield per } \\
\text { plant }(\mathrm{kg})\end{array}$ \\
\hline PK 01 & $3.13 \mathrm{e}-\mathrm{g}$ & $2.27 \mathrm{~g}-\mathrm{i}$ & $5.38 \mathrm{~b}$ & $12.07 \mathrm{c}-\mathrm{f}$ \\
PK 02 & $3.49 \mathrm{c}-\mathrm{f}$ & $3.73 \mathrm{~cd}$ & $5.13 \mathrm{bc}$ & $19.17 \mathrm{ab}$ \\
PK 03 & $5.39 \mathrm{a}$ & $5.78 \mathrm{a}$ & $3.42 \mathrm{~d}$ & $19.75 \mathrm{ab}$ \\
PK 04 & $3.78 \mathrm{~b}-\mathrm{d}$ & $3.29 \mathrm{~d}-\mathrm{g}$ & $4.75 \mathrm{~b}-\mathrm{d}$ & $15.79 \mathrm{a}-\mathrm{e}$ \\
PK 05 & $3.47 \mathrm{c}-\mathrm{f}$ & $2.64 \mathrm{f}-\mathrm{g}$ & $4.68 \mathrm{~b}-\mathrm{d}$ & $12.35 \mathrm{c}-\mathrm{f}$ \\
PK 06 & $3.62 \mathrm{~b}-\mathrm{e}$ & $3.68 \mathrm{c}-\mathrm{e}$ & $4.79 \mathrm{~b}-\mathrm{d}$ & $17.35 \mathrm{a}-\mathrm{d}$ \\
PK 07 & $3.92 \mathrm{bc}$ & $4.86 \mathrm{ab}$ & $4.63 \mathrm{~b}-\mathrm{d}$ & $22.45 \mathrm{a}$ \\
PK 08 & $2.96 \mathrm{fg}$ & $2.68 \mathrm{e}-\mathrm{h}$ & $3.83 \mathrm{~b}-\mathrm{d}$ & $10.65 \mathrm{~d}-\mathrm{g}$ \\
PK 09 & $2.61 \mathrm{~g}$ & $1.88 \mathrm{hi}$ & $7.58 \mathrm{a}$ & $14.27 \mathrm{~b}-\mathrm{f}$ \\
PK 10 & $3.93 \mathrm{bc}$ & $3.61 \mathrm{~d}-\mathrm{f}$ & $4.25 \mathrm{~b}-\mathrm{d}$ & $15.39 \mathrm{~b}-\mathrm{e}$ \\
PK 11 & $3.58 \mathrm{~b}-\mathrm{e}$ & $3.65 \mathrm{c}-\mathrm{f}$ & $3.71 \mathrm{~cd}$ & $13.54 \mathrm{~b}-\mathrm{f}$ \\
PK 12 & $3.77 \mathrm{~b}-\mathrm{d}$ & $3.73 \mathrm{~cd}$ & $3.79 \mathrm{~b}-\mathrm{d}$ & $14.40 \mathrm{~b}-\mathrm{f}$ \\
PK 13 & $4.20 \mathrm{~b}$ & $4.65 \mathrm{bc}$ & $4.04 \mathrm{~b}-\mathrm{d}$ & $18.53 \mathrm{a}-\mathrm{c}$ \\
PK 14 & $3.82 \mathrm{bc}$ & $3.15 \mathrm{~d}-\mathrm{g}$ & $2.96 \mathrm{~d}$ & $10.23 \mathrm{e}-\mathrm{g}$ \\
PK 15 & $3.19 \mathrm{~d}-\mathrm{g}$ & $2.33 \mathrm{~g}-\mathrm{i}$ & $3.25 \mathrm{~d}$ & $7.62 \mathrm{fg}$ \\
PK 16 & $3.11 \mathrm{e}-\mathrm{g}$ & $3.67 \mathrm{c}-\mathrm{f}$ & $5.13 \mathrm{bc}$ & $18.77 \mathrm{a}-\mathrm{c}$ \\
PK 17 & $3.06 \mathrm{e}-\mathrm{g}$ & $1.41 \mathrm{i}$ & $3.50 \mathrm{~d}$ & $4.84 \mathrm{~g}$ \\
PK 18 & $2.95 \mathrm{fg}$ & $3.07 \mathrm{~d}-\mathrm{g}$ & $4.38 \mathrm{~b}-\mathrm{d}$ & $13.39 \mathrm{~b}-\mathrm{f}$ \\
PK 19 & $3.21 \mathrm{~d}-\mathrm{g}$ & $3.50 \mathrm{~d}-\mathrm{f}$ & $4.25 \mathrm{~b}-\mathrm{d}$ & $15.08 \mathrm{~b}-\mathrm{e}$ \\
\hline Range & $2.61-5.39$ & $1.41-5.78$ & $2.96-7.58$ & $4.84-22.45$ \\
CV $(\%)$ & 8.13 & 14.60 & 16.46 & 12.36 \\
\hline
\end{tabular}

Means with uncommon letter(s) differ significantly by DMRT at $1 \%$ level.

\section{Qualitative characters}

Remarkable variation in different qualitative characters of 19 pumpkin inbreds was observed (Table 4). Seven different fruit shapes were recorded of which flat shape (6 inbreds) was dominant over others. Flesh color was categorized as yellow, light yellow, orange and deep orange. Ten inbreds were orange in color and the rest of them were yellow, light yellow and deep orange. Wide range of variability was observed in fruit skin color at mature stage. Fruit skin colour was found as brown, deep brown, brown with green patches, deep brown with green patches and spotted. Spotted and brown with green patches are dominant over other colored types. 
Table 4. Performance of 19 pumpkin inbreds for qualitative characters

\begin{tabular}{l|cccc}
\hline Inbred lines & Fruit shape & Fruit skin color & Flesh color \\
\hline PK 01 & G & B & O \\
PK 02 & E & DB + G patches & LY \\
PK 03 & R & Spotted & Y \\
PK 04 & HF & DB & O \\
PK 05 & F & Spotted & O \\
PK 06 & D & DB & LY \\
PK 07 0 & DB & O \\
PK 08 & HF & Spotted & O \\
PK 09 & F & Spotted & O \\
PK 10 & F & DB & Y \\
PK 11 & G & Spotted & DO \\
PK 12 & F & Spotted & DO \\
PK 13 & F & B + G patches & DO \\
PK 14 & HF & Spotted & O \\
PK 15 & HF & B + G patches & O \\
PK 16 & HF & DB + G patches & O \\
PK 17 & Oval & B + G patches & Y \\
PK 18 & F & Spotted & Y \\
PK 19 & Oval & DB + G patches & O \\
\hline
\end{tabular}

$\mathrm{G}=$ Globular, $\mathrm{E}=$ Elliptical, $\mathrm{F}=$ Flat, $\mathrm{HF}=$ High Flat, $\mathrm{D}=$ Dumble, $\mathrm{R}=$ Round, $\mathrm{B}=$ Brown, $\mathrm{DB}=$ Deep brown, $\mathrm{B}+\mathrm{G}$ patches $=$ Brown with green patches, $\mathrm{DB}+\mathrm{G}$ patches $=$ Deep brown with green patches, $\mathrm{O}=$ Orange, $\mathrm{DO}=$ Deep orange, $\mathrm{Y}=$ Yellow, $\mathrm{LY}=$ Light yellow

\section{Disease and insect reaction}

\section{Fruit fly infestation}

All the inbreds were found to be infested by cucurbit fruit fly (Bactrocera cucurbitae). As control measure was taken earlier, the infestation rate was found very low. Fruit fly infestation varied significantly for different inbred and ranged from 0.12 to $0.77 \%$ (Table 5). The highest fruit fly infestation was recorded in PK05 (0.77\%), while the lowest fruit fly infestation was recorded in PK04 (0.12 \%) which was statistically similar to PK11 (0.16 \%), PK18 (0.17 \%) and PK16 $(0.19 \%)$. 


\section{Virus incidence (\%)}

All the tested inbreds were found to be infested by Water Melon Virus 2 (WMV2). Among the inbreds significant differences was found in respect of virus incidence ranging from 0.0 to $100 \%$ (Table 5). The highest virus incidence was recorded in PK06 (75\%) while virus incidence was not found in four inbreds viz., PK05, PK16, PK17 and PK18. This result could be more conclusive if it was conducted under epiphytic condition with optimum inoculum pressure. However, this preliminary information could be helpful to the breeder during parent selection for hybridization program.

Table 5. Fruit fly infestation and virus incidence in 19 pumpkin inbreds

\begin{tabular}{|c|c|c|}
\hline Inbreds & ${ }^{1}$ Fruit fly infestation (\%) & ${ }^{2}$ Virus incidence $(\%)$ \\
\hline PK 01 & $0.34 \mathrm{de}(3.34)$ & $14.5 \mathrm{f}(3.87)$ \\
\hline PK 02 & $0.29 \mathrm{~d}-\mathrm{g}(3.09)$ & $34.0 \mathrm{~d}(5.87)$ \\
\hline PK 03 & $0.53 \mathrm{~b}(4.17)$ & $8.8 \mathrm{~g}(3.05)$ \\
\hline PK 04 & $0.12 \mathrm{j}(1.98)$ & $36.5 \mathrm{~d}(6.08)$ \\
\hline PK 05 & $0.77 \mathrm{a}(5.03)$ & $0.0 \mathrm{~h}(0.71)$ \\
\hline PK 06 & $0.25 \mathrm{f}-\mathrm{h}(2.86)$ & $75.0 \mathrm{a}(8.69)$ \\
\hline PK 07 & 0.33 d-f (3.29) & $12.5 \mathrm{fg}(3.60)$ \\
\hline PK 08 & $0.23 \mathrm{~g}-\mathrm{i}(2.75)$ & 50.0 c (7.11) \\
\hline PK 09 & 0.45 c $(3.84)$ & $17.8 \mathrm{f}(4.28)$ \\
\hline PK 10 & 0.34 de $(3.34)$ & $8.3 \mathrm{~g}(2.97)$ \\
\hline PK 11 & $0.16 \mathrm{ij}(2.29)$ & $34.0 \mathrm{~d}(5.87)$ \\
\hline PK 12 & $0.36 \mathrm{~d}((3.44)$ & 25.5 e $(5.05)$ \\
\hline PK 13 & $0.51 \mathrm{bc}(4.09)$ & $58.5 \mathrm{~b}(7.65)$ \\
\hline PK 14 & $0.29 \mathrm{~d}-\mathrm{g}(3.09)$ & 24.5 e $(5.00)$ \\
\hline PK 15 & 0.34 de $(3.34)$ & 25.3 e $(5.08)$ \\
\hline PK 16 & $0.19 \mathrm{~h}-\mathrm{j}(2.50)$ & $0.0 \mathrm{~h}(0.71)$ \\
\hline PK 17 & 0.27 e-h (2.98) & $0.0 \mathrm{~h}(0.71)$ \\
\hline PK 18 & $0.17 \mathrm{ij}(2.36)$ & $0.0 \mathrm{~h}(0.71)$ \\
\hline PK 19 & $0.24 \mathrm{~g}-\mathrm{i}(2.81)$ & $16.8 \mathrm{f}(4.16)$ \\
\hline Range & $0.12-0.77$ & $0.0-75$ \\
\hline $\mathrm{CV}(\%)$ & 12.0 & 11.2 \\
\hline
\end{tabular}

${ }^{1}$ Figures within the parenthesis are arcsin-transformed values

${ }^{2}$ Figures within the parenthesis are square root $(\sqrt{ } \mathrm{x}+0.5)$ transformed values

\section{Conclusion}

Based on the above discussion, it can be concluded that nine inbreds viz., PK01, PK02, PK03, PK06, PK07, PK08, PK09, PK10 and PK16 might be suitable for the development of high yielding pumpkin varieies with better quality through hybridization. 


\section{References}

Ahmed, K.U., B. Akhter, M.R. Islam, N. Ara and M.R. Humauan. 2011. An assessment of morphological and yield characteristics of Pumpkin (Cucurbita moschata Duch Ex. Poir) genotypes in Northern Bangladesh. Trop. Agril. Res. Ext. 14(1): 07-11.

Akter, L., M.A.T. Masud and M. H. Al - Mamun. 2011. Advanced yield trial in pumpkin. Research Report. Horticulture Research Centre, Bangladesh Agriculture Research Institute. P. 33.

Akter, S., M.G. Rasul, A.K.M. A. Islam and M.M. Hossain. 2013. Genetic variability, correlation and path co-efficient analysis of yield and quality traits in pumpkin (Cucurbita moschata Duch Ex. Poir). Bangladesh J. Pl. Breed. Genet. 26(1): 25-33.

Anonymous. 2012. Fertilizer Recommendation Guide 2012. Bangladesh Agricultural Research Council, Farmgate, Dhaka.1215.

Aruah, C.B., M.I. Uguru and B.C. Oyiga. 2012. Genetic variability and interrelationship among some Nigerian pumpkin accessions (Cucurbita spp). Int. J. Pl. Breed. 6(1): 34-41.

BBS (Bangladesh Bureau of Statistics). 2013. Year Book of Agricultural Statistics. Statistics and Information Division, Ministry of Planning, Bangladesh, Dhaka. p. 41.

Gupta, P. N. and M. Rai. 1990. Genetic divergence in cucurbit-pumpkin. Indian Hort. 36:1.

Hazra, P., A. K. Mandal, A. K. Datta and H. H. Ram. 2007. Breeding pumpkin (Cucurbita moschata Duch. Ex Poir.) for fruit yield and other characters. Int. J. Pl. Breed. 1(1): 51-64.

Islam, F., L. Akter and M. Zashimuddin. 2009. Collection and evaluation of pumpkin germplasm. Ann. Res. Rpt. Olericulture Division, BARI. Pp. 30-31.

Kamaluddin, A. S. M. 1996. Sabjir Chash (In Bengali). Kamrunnahar, Mohammadpur, Dhaka, Bangladesh. $258 \mathrm{Pp}$.

Mohanty, B.K. and R.S. Mishra. 2002. Studies on heterosis for flowering attributes in pumpkin (Cucurbita moschata Duch Ex. Poir.). South Indian Hort. 47(1-6):203-205.

Pandey, S., J. Singh, A.K. Upashyay, D. Ram. and M. Rai. 2003. Ascorbate and carotenoid content in an Indian collection of pumpkin (Cucurbita moschata Duch Ex. Poir). Cucurbit Genetics Cooperative Report. 26: 51-53.

Rashid, M.M. 1993. Shabji Biggyan (In Bengali). Bangla Academy, Dhaka. Bangladesh. $515 \mathrm{Pp}$.

Rashid, M.M. 1999. Shabji Biggyan (In Bengali). Rashid Pub. House, 94, Old DOHS, Dhaka-1206. 526 Pp.

Rasul, M.G. and M.S. Raihan. 2014. Development of small fruited high quality pumpkin (Cucurbita moschata Duch Ex Poir) varieties. Project Report. Dept. of Genetics and Plant Breeding, BSMRAU, Gazipur.

Rouf, M.A., M.M. Ullah and M.M. Rahman. 2011. Evaluation of different pumpkin genotypes. Research Report on Horticultural crops. Horticulture Research Centre. BARI. P. 61. 
